\title{
Efficient Method on Energy Regeneration through Speed Breakers
}

\author{
Manoj Kumar, K. N. S. Rahul, Smt Malathi Narra, B. Pandu RangaRao
}

\begin{abstract}
From the last century speed breaker is been the sedulous thing in controlling the speed on roads. But as the technology and requirements in vehicular design increased over time, the design of vehicles having the ability to move at high speeds had ameliorated. Speed breakers with the intent of controlling speed had been doing great damage to the vehicular functioning and been gist in fuel wastage if the vehicle crosses the limits.
\end{abstract}

To utilize the present exhausting resources efficiently, every black point has to be covered and recovery of lost energy has to be the main aim. So the energy lost by a vehicle in negotiating a speed breaker has to be recuperated. This can be brought to fruition by utilizing an energy regenerating speed breaker.

Many attempts had carried out in creating an efficient energy regenerating speed breaker, every method proposed had involved in outlasting the energy generation and carried a hitch. This paper deals with a newfangled method in the renewal of energy involving the principles of negative suction.

Index words: ameliorated, fruition, newfangled, negative suction.

\section{INTRODUCTION}

In the last 300 years, the invention of electricity changed the fate of the world from gloom to gleam. Modern humans had evolved into such a way that his day will be an incomplete thing without electricity. Many new techniques had evolved in the last century which can't handle the demand for electricity in the present modern-day, so there got a great insistent on finding every possible way of generating electricity.

Including piezoelectric sensors, thermoelectric effect, micro solar panels to wearable sensors flushed the last decade's demand for electricity. But a fact which cloistered them is those process involves high initial and maintenance cost.

Speed breaker to control the speeds of vehicles was invented in 1927 by a noblest in physics "Arthur Holly Compton". Coming to our county's scenario, Indian road congress in their code IRC 99-1988, gave a clear-cut design for a speed breaker. But as time passed from 20 th to 21 st century many of the contractors started laying speed breakers with their design with a view of the economy. It is a well-known fact that economy and safety can't be placed into the same box resulted in many deaths and accidents in the Indian subcontinent. The above two stories had two different plots which can be ended with a single climax "A PRECAST POWER GENERATING SPEED BREAKER”.

\section{LITERATURE SURVEY}

ZiyuAmaize Peter Et al designed a model using a Permanent Magnet Direct Current (PMDC) generator, through springs, ball bearings, rack, and pinion gear.

Revised Manuscript Received on January 05, 2020.

E. Manoj Kumar pursuing Bachelor of technology in civil engineering at VR Siddhartha Engineering College.

Kunapareddy Naga Sai Rahulpursuing bachelor of technology in civil engineering at VR Siddhartha Engineering College.

SmtMalathiNarraM.Tech(PhD) MIRC,MISTE,MICI

Assistant Professor,Civil Engineering Department,VR Siddhartha Engineering College,malathin76@gmail.com

Dr. B.PandurangaRao, M.E, PhD, ACCE, CE,FIE, FIV, LMISTE

Dean and Professor, V.R.Siddhartha.
Results obtained from that system showed that it generates a higher voltage at a lower speed limit and a lower voltage at a higher speed limit. He started making those type of models due to the power shortage in the Nigerian power sector, countering the low power production the results shown that $4.9 \mathrm{MWh}$ of electric energy could be generated if the vehicular traffic situation in Nigeria is seeing it as an advantage [1]

Ajaysinh, rushabh, Ronak, Chintan designed a power generating speed breaker using rack\& pinion mechanism which has a horizontal surface plate that takes the loads/potential energy from the vehicles. The horizontal plate is connected to a rack and in turn a pinion that is coupled to gear mechanisms. The gears rotate the shaft of the dynamo which generates electricity. It is assumed that a $500 \mathrm{~kg}$ vehicle produces 11.34 volts of EMF. The rack and pinion method is found to be more effective, economical easy to implement too [2].

Prof. Sandhya Et al concludedthat vertical deflection is causedin the speed breaker when an oncoming vehicle passes over it which results in the release of thermal energy. Piezoelectric sensors were employed here to generate electricity [3].

Noor Fatima, Jiyaul Mustafa says that electricity can be generated by the rotary motion delivered by the crank mechanism, which is obtained by installing a moving plate on road. Standard procedures have been employed in the design of components [4].

JianzhongPei Et al worked on another method for the harvesting of energy from roads. Projection of shortages in conventional energy sources have lead humans to utilize renewable resources. Primarily there are three methods in harvesting energy from roads like piezo, thermal, and photo electricity.

This paper concentrated on dynamic heat light division recommendations based on the literature. They coined the word e-roads which have the potential to serve as one of the largest sources of energy in the nearby future. Their study laid a path to future construction and road network planning [5].

R.D.Sharma Et al Observed that the mass of a car is used to throw a lever which is called a rack and pinion method. When any vehicle passes over the rack, it movies down and the pinion starts rotating which is later converted is explained by Gerard Lynch,one of the engineers behind the Motion Power system developed for New Energy Technologies, a Maryland-based company. "The instantaneous power is 2,000 watts at five miles-per-hour, but it's instantaneous which means some form of storage will be required [6].

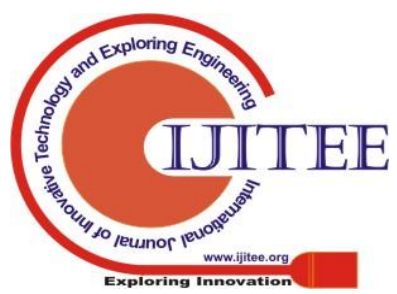


Another model for generating power by the connection of rotor (rotating shaft) directly to the prime mover and rotates as the prime mover turns. The rotor contains a magnet that, when turned, produces a moving or rotating magnetic field. The rotor is surrounded by a stationary casing called the stator, which contains the wound copper coils or windings. When the moving magnetic field passes by these windings, electricity is produced in them. By controlling the speed at which the rotor is turned, a steady flow of electricity isproduced in the windings. These windings are connected to the electricity network via transmission lines. IIT Guwahati has evaluated the machine and recommended it to the Assam ministry of power for large scale funding. IIT design department says it is a very viable proposition ${ }^{\text {ee }}$ to utilize the thousands of MW of power untapped across the country every day. A vehicle weighing $1000 \mathrm{~kg}$ going up a height of $10 \mathrm{~cm}$ on such a rumble strip harvests about $0.98 \mathrm{KW}$ power. so we can imagine how much energy will be generated daily on our Indian highways. The cost of electricity generation and storage per MW from speed breaker is nearly $1 \mathrm{cr}$ as compared to Rs 8cr hydro and thermal power station[7]

Arnab Et al shares that the usage of combined piezo and solar panels in the electricity generation can help us fulfilling the needs of electrical power necessary for our future. The setup of piezo and solar was attached to a speed breaker, to tame large amounts of electricity which might be used in lighting the street lamps[8].

ZiyuLiua Et al shares that the sustainable growth can be achieved when the energy utilized is produced without affecting the nature and converting the energy in an efficient way. Large amount solar radiation is been wasting on the roads.In this paper, they propose a plan to estimate the amount of solar light/radiation on the roads and the amount of solar energy that can be produced by using efficient solar panels from it. Google Street View images are collected to know the position of different geographic details in the locations as they indirectly effect the solar radiation by blocking sun rays and reduces efficiency of the system. In addition to buildings, they also take the impact of traffic conditions and weather situations into consideration in the calculation. Therefore, radiation maps at different times in a year are produced to analyze the road's photovoltaic capacity and distribution. To test the feasibility of the plan, Boston city is taken as case study. Results show that roads in Boston can generate efficient electricity for all future electric vehicles in the city [9].

Roshani H Et al shares that the piezoelectric sensors coupled with the pavement will show a promising path in powering the LED traffic lights. They developed many models which deal in calculating the amount of power that can be produced fro, the piezoelectric coupled pavements. their study shows a future where micro power generating systems will complete the humans power requirements in future [10].

Wei Jianga Dong Et al al shares that energy that can be generated from the road has become a study place. The power developing system within asphalt pavement based on thermoelectric technology was studied in this paper. The aspects of the temperature difference between the pavement and surrounding air, as well as the temperature differencewithin the road surface, were examined by collecting data on-site in different seasons. Based on this, an ideal set of road thermoelectric generator system (RTEGS) was developed, which can generate radioactivity when there is a temperature difference between the road surface and surrounding air. Besides, an RTEGS prototype was fabricated to verify the energy generation capacity based on indoor and outdoor tests. Results showed that the output voltage of RTEGS was about $0.4 \mathrm{~V}$ by asphalt mixture slab $(300 \mathrm{~mm} \times$ $300 \mathrm{~mm}$ by size) when the temperature difference between the road surface and ambient air was $15{ }^{\circ} \mathrm{C}$ in winter. While in summer, the output voltage was about $0.6-0.7 \mathrm{~V}$, with a temperature difference of $25-30{ }^{\circ} \mathrm{C}$. This means that some $160 \mathrm{~kW}$ h of energy can be obtained in $8 \mathrm{~h}$ from a road of 1 $\mathrm{km}$ in length and $10 \mathrm{~m}$ in width. For an asphalt road in tropical and subtropical regions, the large temperature difference would be more suitable for RTEGS. The discoveries and research experiments from this study will provide a good starting point and reference for the improvement and application of pavement thermoelectric technology.[11]

\section{There are some notable mentions:}

Some exceptional people contributed their knowledge in the evolution of new techniques in the generation of electricity from speed breakers. They were quoted in the table below

\begin{tabular}{|c|c|c|}
\hline Author & Title of work & $\begin{array}{l}\text { Sap of the } \\
\text { work }\end{array}$ \\
\hline $\begin{array}{l}\text { Pankaj D. Jagtap } \\
\text { (July 2014) }\end{array}$ & $\begin{array}{l}\text { A Review: } \\
\text { Comparison of } \\
\text { different } \\
\text { Mechanisms for } \\
\text { Electricity } \\
\text { Generation using } \\
\text { Speed Breaker }\end{array}$ & $\begin{array}{l}\text { In this } \\
\text { paper,theautho } \\
\mathrm{r} \text { compared the } \\
\text { different } \\
\text { mechanisms } \\
\text { and concludes } \\
\text { that Rack and } \\
\text { pinion } \\
\text { mechanism is } \\
\text { the best } \\
\text { suitable one } \\
\text { compared to } \\
\text { remaining }\end{array}$ \\
\hline $\begin{array}{l}\text { G.RamakrishnaPrabu, } \\
\text { G.Ethiraj } \\
\text { ( May 2015) }\end{array}$ & $\begin{array}{l}\text { Electricity Generation } \\
\text { by Speed Breaker }\end{array}$ & $\begin{array}{l}\text { He deals with } \\
\text { the model of } \\
\text { rack and } \\
\text { pinion,analyze } \\
\mathrm{s} \text { the average } \\
\text { power that can } \\
\text { be produced in } \\
\text { a driveway }\end{array}$ \\
\hline Dave Jaymin J(2015) & $\begin{array}{l}\text { Power Generation } \\
\text { from Speed Breakers } \\
\text { by Air Compression } \\
\text { Method }\end{array}$ & $\begin{array}{l}\text { He employees } \\
\text { the piston } \\
\text { mechanism and } \\
\text { gave results } \\
\text { about the } \\
\text { undefined } \\
\text { structure of the } \\
\text { piston } \\
\text { mechanism }\end{array}$ \\
\hline $\begin{array}{ll}\text { Anyaegbunam } & \text { F.N.C } \\
\text { (September 2015) } & \end{array}$ & $\begin{array}{l}\text { Electric Power } \\
\text { Generation by Speed } \\
\text { Breaker Generators }\end{array}$ & $\begin{array}{l}\text { He uses a lever } \\
\text { mechanism } \\
\text { which is similar } \\
\text { to a rack and } \\
\text { pinion } \\
\text { mechanism }\end{array}$ \\
\hline
\end{tabular}




\begin{tabular}{|c|c|c|}
\hline $\begin{array}{l}\text { G.Vamsi Krishna, } \\
\text { SeeramSrinivasarao, } \\
\text { P.Sriharsha, B.V.Neerav, } \\
\text { G.E.N.M.S.Satyasai } \\
\text { (May 2019) }\end{array}$ & $\begin{array}{l}\text { Modeling \&Analysis } \\
\text { of Flat Spiral Spring } \\
\text { Based Speed Breaker } \\
\text { Device for Generation } \\
\text { of Electricity }\end{array}$ & $\begin{array}{l}\text { He gives a } \\
\text { detailed model } \\
\text { of rack and } \\
\text { pinion along } \\
\text { with the stress } \\
\text { distribution in } \\
\text { the spring } \\
\text { material } \\
\text { employed. }\end{array}$ \\
\hline $\begin{array}{l}\text { Ali Azama, }{ }^{*}, \quad \text { M. } \\
\text { AqeelAslamb, Shoukat Alia, } \\
\text { F.Q. Yousef-Zaib } \\
(2016)\end{array}$ & $\begin{array}{l}\text { Speed Breaker Power } \\
\text { Generator }\end{array}$ & $\begin{array}{l}\text { He gives the } \\
\text { load to the } \\
\text { electricity } \\
\text { generation } \\
\text { principle by } \\
\text { conducting a } \\
\text { standard table } \\
\text { speed breaker } \\
\text { test }\end{array}$ \\
\hline $\begin{array}{l}\text { Kafi Mohammad Ullah1, K. } \\
\text { M. Ahsan-uz-Zaman2, } \\
\text { Sohag Hosen3, } \\
\text { RakibulHasan } \quad \text { Khan4, } \\
\text { Sanjida Parvin5 } \\
(2016)\end{array}$ & $\begin{array}{lr}\begin{array}{l}\text { Electrical } \\
\text { generation }\end{array} & \text { power } \\
\text { through }\end{array}$ & $\begin{array}{l}\text { He improves the } \\
\text { rack and pinion } \\
\text { model by adding } \\
\text { a flywheel to it, } \\
\text { to store the } \\
\text { energy }\end{array}$ \\
\hline $\begin{array}{l}\text { Shah MohazzemHossaina, }{ }^{*} \text {, } \\
\text { C. K. Dasb, Md. } \\
\text { ShahdatHossanc, } \\
\text { SamsJarind (2015) }\end{array}$ & $\begin{array}{l}\text { Electricity from } \\
\text { Wasted Energy of the } \\
\text { Moving Vehicle Using } \\
\text { Speed Breaker }\end{array}$ & $\begin{array}{l}\text { They employees } \\
\text { a roller } \\
\text { mechanism and } \\
\text { conducts some } \\
\text { tests by letting } \\
\text { truck, auto, } \\
\text { two-wheeler } \\
\text { over the roller } \\
\text { mechanism and } \\
\text { calculates the } \\
\text { power that can } \\
\text { be produced. }\end{array}$ \\
\hline $\begin{array}{l}\text { OmkarKalbhor } \\
\text { Prof. J.V.Chopade } \\
\text { ( Feb, 2017) }\end{array}$ & $\begin{array}{l}\text { Study and } \\
\text { Analysis of Power } \\
\text { Generation by } \\
\text { Speed Breaker-A } \\
\text { Review }\end{array}$ & $\begin{array}{l}\text { He gives a new } \\
\text { name to the } \\
\text { speed breaker by } \\
\text { calling it as a } \\
\text { power hump, he } \\
\text { uses a traditional } \\
\text { rack and pinion } \\
\text { method as the } \\
\text { core mechanism }\end{array}$ \\
\hline $\begin{array}{l}\text { RupareliyaDivyesh } \\
\text { Patel Parth } \\
\text { Patel Hirenkumar } \\
\text { (June, 2017) }\end{array}$ & $\begin{array}{l}\text { Proposed Work on } \\
\text { the Road Power } \\
\text { Generation } \\
\text { through Speed } \\
\text { Breaker }\end{array}$ & $\begin{array}{l}\text { He gives an } \\
\text { outlook of the } \\
\text { production of } \\
\text { speed breakers } \\
\text { commercially by } \\
\text { balancing the } \\
\text { economic and } \\
\text { power } \\
\text { generation } \\
\text { abilities is a } \\
\text { balance. }\end{array}$ \\
\hline $\begin{array}{l}\text { AkashLiladharGorleAkashNaren } \\
\text { draPatil } \\
(2018)\end{array}$ & $\begin{array}{l}\text { Literature Review } \\
\text { on Electricity } \\
\text { Generation using } \\
\text { Speed Breaker" }\end{array}$ & $\begin{array}{l}\text { It was a detailed } \\
\text { comparison of } \\
\text { different } \\
\text { mechanisms like } \\
\text { air piston } \\
\text { mechanism, rack } \\
\text { and pinion } \\
\text { mechanism, } \\
\text { roller } \\
\text { mechanism, } \\
\text { spring table } \\
\text { mechanism. }\end{array}$ \\
\hline $\begin{array}{l}\text { Swapnil K. Jari, Vivek N. Gawai } \\
\text { (February 2017) }\end{array}$ & $\begin{array}{l}\text { Power Generation } \\
\text { by Speed Breaker }\end{array}$ & $\begin{array}{l}\text { He gives a } \\
\text { detailed review } \\
\text { of different } \\
\text { mechanisms that } \\
\text { can be employed } \\
\text { in the generation } \\
\text { of power from } \\
\text { the speed } \\
\text { breaker and } \\
\text { suggests }\end{array}$ \\
\hline
\end{tabular}

As time passed many new mechanisms in producing energy from the movement of vehicles over a speed breaker had produced. They include the roller mechanism, use of rack and pinion, air pistons, and piezoelectric sensors on the top surface. Every mechanism involved the mechanical parts or materials that can be affected easily by the natural phenomenon. To counter every drawback caused in each mechanism pressure controlled cylinders were used. The details of the mechanisms were given below.

\section{Roller mechanism:}

This is an old and simple technique for electricity generation. This system deals w8ith the transfer of the rotational energy of the vehicle wheel to the driving shaft of the DC dynamo which produces energy. The instrumental setup consists of two wooden or metal slopes which join at one end over a metal roller over which the vehicles had to pass while passing the wheels rotate roller and in turn the dynamo and a finally some amount of energy is converted into electrical energy

The power produced in the mechanism is in D.C form. The voltage of current produced by this depends mainly on the efficiency of the conversion mechanism and the DC dynamo

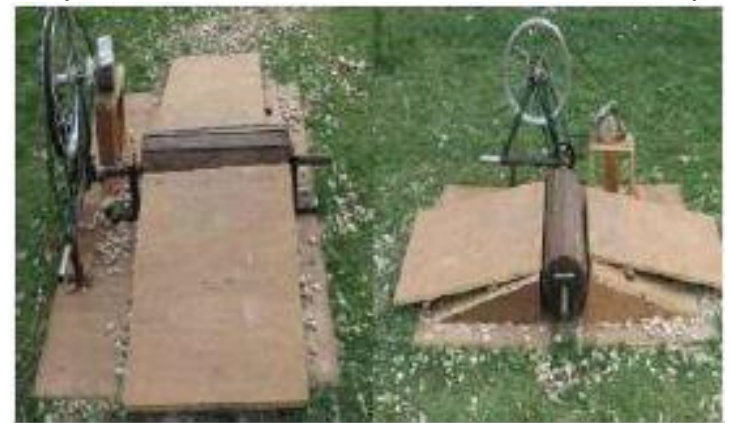

Fig: 1 ROLLER MECHANISM

\section{Rack and Pinion Mechanism:}

To overcome the energy losses in roller mechanism and increase the efficiency of production rack and pinion mechanism is developed. It consists of a grooved vertical rod(rack) attached to a small gear(pinion).The rack and pinion mechanism works on To and Fro motion of rack and rotator motion of pinion. The top part of the rack being connected to the bottom edge of speed breaker when a vehicle moves over it and presses the speed breaker due to its weight the rack moves downward which turns the pinion attached to it clockwise direction. The axis of the pinion is attached to the sprocket arrangement on the shafts. The sprocket arrangement is made of two sprockets, one larger and the other smaller. Both the sprockets were connected through the chain which serves in transmitting power from the larger sprocket to the smaller sprocket. As the power is transmitted from the larger sprocket to the smaller ones, torque that is stored in the larger sprocketincreases.. As the smaller sprocket rotates, the shaft rotates which in turn rotates the shaft of motor using a gear system.

A flywheel is attached to the shaft of the smaller sprocket to get an uninterrupted rotation of the shaft and thus the generator. Electricity is produced when the pinion rotates in a clockwise direction while the rack is moving in upward direction,the pinion will rotate it in an anticlockwise direction and cancel the movement of the clockwise direction, hence the efficiency of the overall system decreases.

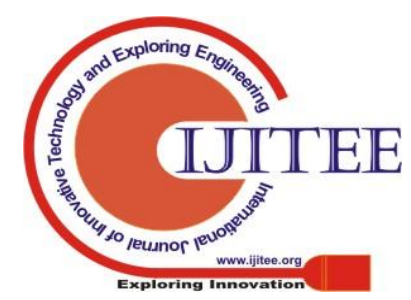


This mechanism is also limited to light usage due to its more wear and tear properties, as when it is subjected to more movements the grooves of rack and pinion may worn out causing slippage and finally failure of the speed breaker.

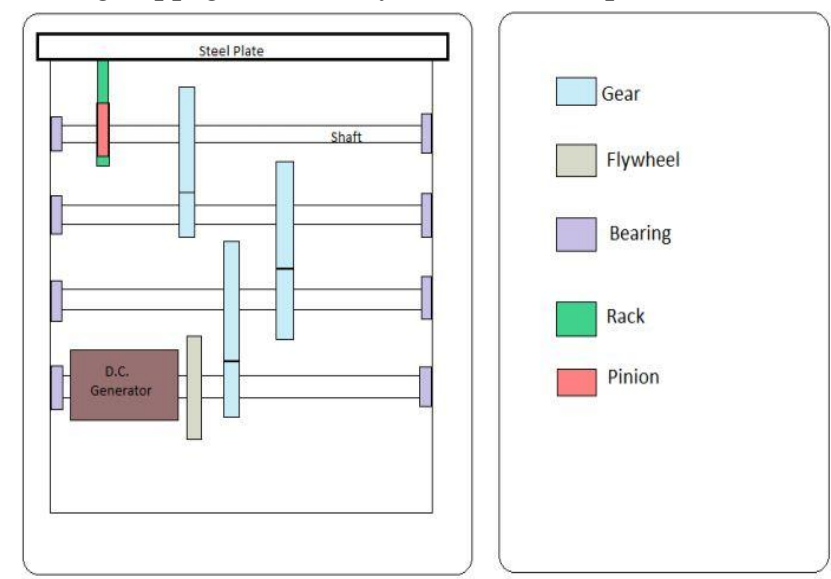

Fig:2 RACK AND PINION DESIGN

\section{Air Piston Mechanism:}

It is a different kind of approach, where pistons were employed in neutralizing the impact force caused by an upcoming vehicle on a speed breaker and converting that impact force into compressed air. The system consists of a circular piston whose handle and the lower part were connected by a spring coil, the cylinder is has an inlet valve in its top portion for the intake of air and an outlet valve for expelling it. When a vehicle negotiates this type of assembly The piston handle goes down and after the vehicle passes by, with the help of spring the handle regains its original position Every mechanism developed has theirlimitation, even this air piston mechanism too, there is no system designed for the cooling of piston caused by the rapid working of the piston and the spring may losses its ability by a long run due to creep.

Beside many limitations, it is one of the clean and finest energy producing system compared to remaining models. The amount of compressed air produced is utilized in generating electricity. Less number of mechanical parts were employed in this system when compared to rack and pinion mechanism or roller mechanism

Table 1: Comparison table

\begin{tabular}{|c|l|l|l|l|l|}
\hline S & parameters & $\begin{array}{l}\text { Roller } \\
\text { mechanis } \\
\mathrm{m}\end{array}$ & $\begin{array}{l}\text { Rack and } \\
\text { pinion } \\
\text { mechanism }\end{array}$ & $\begin{array}{l}\text { Air } \\
\text { piston } \\
\text { mecha } \\
\text { nism }\end{array}$ & $\begin{array}{l}\text { Piezoelect } \\
\text { ric } \\
\text { mechanis } \\
\mathrm{m}\end{array}$ \\
\hline 1 & Cost & Cheap & Moderate & Costly & Costly \\
\hline 2 & $\begin{array}{l}\text { Mechanica } \\
\text { 1 setup }\end{array}$ & Very easy & Easy & $\begin{array}{l}\text { Difficu } \\
\text { tt }\end{array}$ & Easy \\
\hline 3 & $\begin{array}{l}\text { Maintenan } \\
\text { ce }\end{array}$ & $\begin{array}{l}\text { Required } \\
\text { less }\end{array}$ & $\begin{array}{l}\text { Weekly } \\
\text { basis }\end{array}$ & $\begin{array}{l}\text { Daily } \\
\text { basis }\end{array}$ & $\begin{array}{l}\text { Moderatel } \\
\text { y }\end{array}$ \\
\hline 4 & Efficiency & $50 \%$ & $70 \%$ & $85 \%$ & $\begin{array}{l}\text { Depends } \\
\text { upon } \\
\text { sensors } \\
\text { used }\end{array}$ \\
\hline 5 & Design & easy & $\begin{array}{l}\text { Depends } \\
\text { upon load }\end{array}$ & $\begin{array}{l}\text { Depen } \\
\text { ds } \\
\text { upon } \\
\text { load }\end{array}$ & \begin{tabular}{l} 
easy \\
\hline
\end{tabular} \\
\hline
\end{tabular}

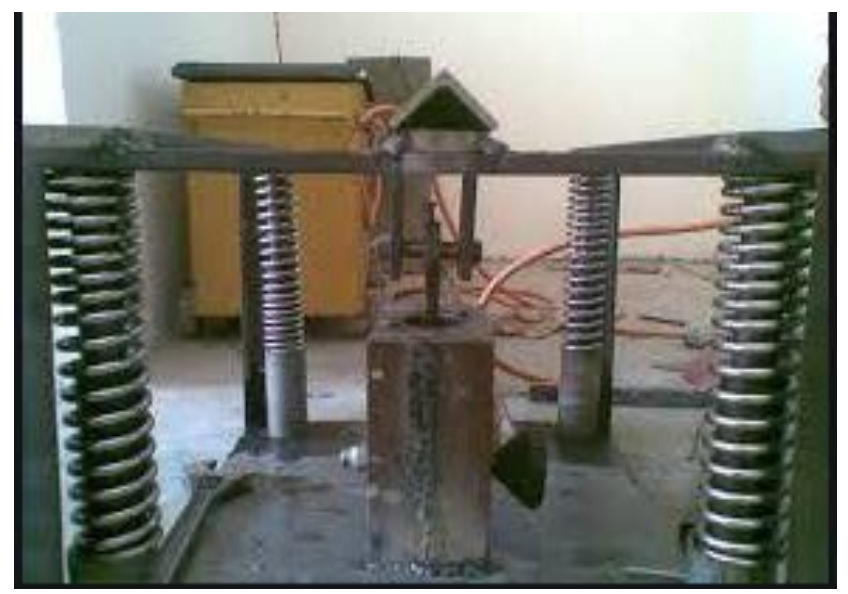

FIG: 3 AIR PISTON MECHANISMS

\section{Piezoelectric sensors}

Piezoelectric sensors were invented by perrie curie in mid $19^{\text {th }}$ century. They under a special effect called piezoelectric effect which delivers the theory that when a piezoelectric material is stressed it creates some negative and positive charge centres. Due the voltage difference between those two points electrical energy can be created. Most troublesome issue in using piezoelectric sensors is that they do not contribute to constant voltage and the amperage is low. Therefore these type of systems has to be employed in micro power generating systems for ultra low power solutions. The mechanism is in the form of below fig 4 .

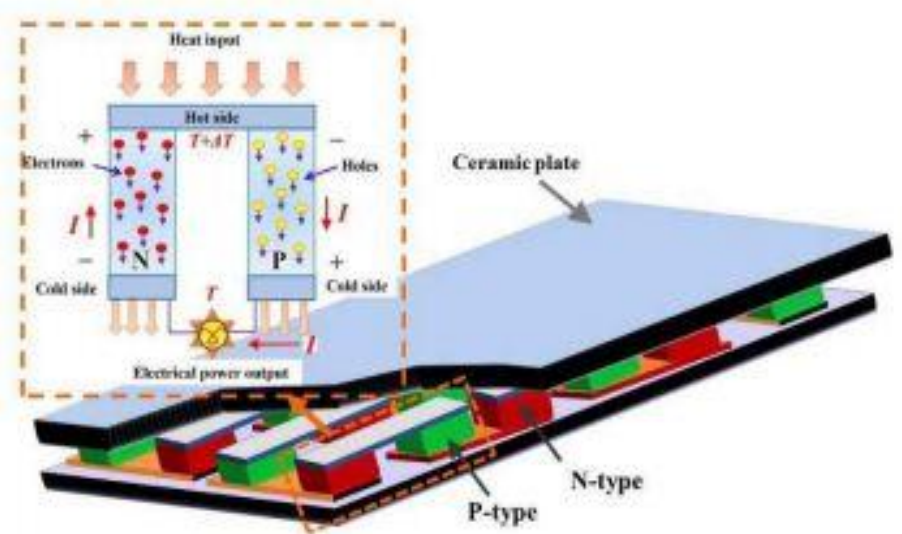

Fig: 4 PIEZOELECTRICMODEL

\section{TABLE OF COMPARISON}

This table shows the parameters like cost, mechanism, maintenance, efficiency and design of different power generating speed breaker models.(Table 1)

\section{METHODOLOGY}

A new design has been adopted for the speed breaker involving all the pros of the above mechanisms and countering all the cons. The design involves the usage of valves attached to the piston model to control the flow of air in and out and the physical phenomenon of negative suction pressure. A new arrangement is made for the controlling of heat produced due to the compression of fluid.

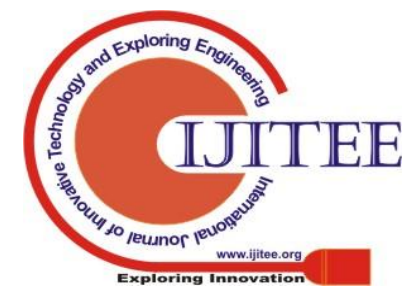


The model includes physical design according to the norms of IRC 1988. The whole lengthwise section of the speed breaker will be divided into strips of definite width. And the cross-sectional is filled with a series of newly designed pistons. The valve used in the piston is TESLA VALVE combined with a single ONE WAY VALVE. The whole surface of the cylinder is covered by another layer in an insulating manner, between which a temperature controlling fluid is placed. Coming to the production of electricity, the pressurized air is collected by a cylinder fitted in the flit space of the speed breaker. When the pressure in the cylinder reaches the pre-assumed value, it opens off to a power tunnel in the frit space where the dynamo is connected with a helical cross-sectioned tunnel.

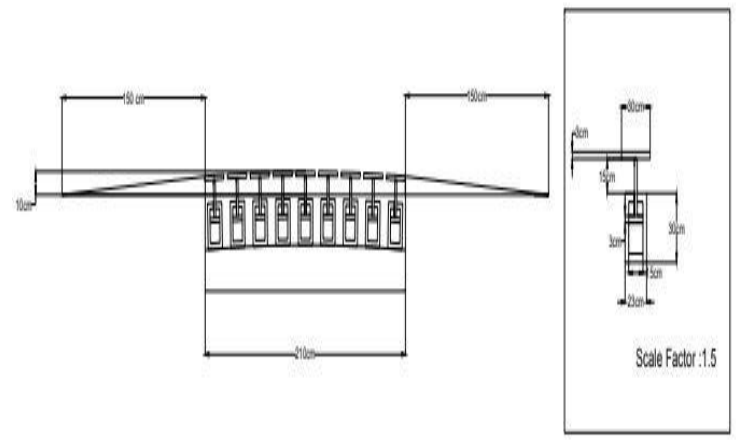

Fig 6: The cross-section of speed breaker assembly

\section{CONCLUSION}

I. We can develop a new presumption in power engendering by the coupling of electrical $\&$ physical principals with civil engineering material like a speed breaker.

II. Utilization of the valve controlled design will give an efficient way of regenerating energy lost in negotiating the speed breaker.

III. Impediments in the early designs will be amended in the valve controlled speed breaker and it may lead to sustainable futuristic advancement in transportation.

\section{REFERENCES}

1. Amaize Peter Aigboviosa, Uzairue Stanley Idiake, NsikanNkordeh, AIROBOMAN Abel Ehimen, and Kasuwa Victory in Development of Electrical Power Generation System Through the Use of Speed Breaker,In Proceedings of the International Conference on Industrial Engineering and Operations Management Washington DC, USA, September 27-29, 2018

2. Ajaysinh, Rushabh, Ronak, Chintan from S.R.P.E.C College "Power Generation from Speed Breaker".

3. Prof. Sandhya B in "Energy Harvesting through Speed Breakers Using Piezoelectric" in International Journal of Innovative Research in Science, Engineering and Technology Vol 7, Special Issue 6, May 2018.

4. Noor Fatima, Jiyaul Mustafa in "Production of electricity by the method of road power generation" in International Journal of Advances in Electrical and Electronics Engineering vol 1.

5. Jianzhong, Pei Bochao Zhou, Lei Lyu in e-Road: The largest energy supply of the future? Applied Energy 241 (2019) 174-183176.

6. R.D.Sharma, S.Jain, K.Singh, "Growth rate of motor vehicles in India", Journal of economics and social studies, Vol.I, 2011.

7. S. Srivastava, A. Asthana,"Produce electricity by the help of speed breakers", Journal of engineering research and studies, Journal of Engineering Research and Studies, Vol.II, April-June, 2011.

8. Arnab, M.M.B., Pal, A.K. Ullah, S.M.R.,Hoque, "A noble model for harvesting energy using piezoelectric material and solar panel: Bangladesh perspective", a conference paper.
9. Ziyu Liu, "Towards feasibility of photovoltaic road for urban traffic-solar energy estimation using street view image", Journal of Cleaner Production Volume 228, 10 August 2019, ||303-318.

10. A.T. Papagiannakisa, S. Dessoukyb, A. Montoya and $\mathrm{H}$ Roshanid, "Energy Harvesting from Roadways" The 6th International Conference on Sustainable Energy Information Technology (SEIT 2016)\| $758-762$. 